DOI:10.17951/h.2019.53.1.39-48

\begin{tabular}{lcl}
\hline & A N N A L E S \\
UNIVERSITATIS MARIAE CURIE-SKŁODOWSKA \\
LUBLIN - POLONIA \\
SOL. LIII, 1 & SECTIO H \\
\hline
\end{tabular}

\author{
MAREK KUŹMICKI \\ m.kuzmicki@dydaktyka.pswbp.pl \\ Pope John Paul II State School of Higher Education in Biała Podlaska, Poland \\ ORCID ID: https://orcid.org/0000-0002-0581-9600
}

\title{
Modern information and communication technologies in the market of hotel services
}

Keywords: technology; hospitality; development

JEL: O30; O33; Z32

How to quote this paper: Kuźmicki, M. (2019). Modern information and communication technologies in the market of hotel services. Annales Universitatis Mariae Curie-Skłodowska, sectio H-Oeconomia, Vol. 53, No. 1.

\begin{abstract}
Theoretical background: The development of new technologies has a considerable impact on the functioning of numerous service industries. The market of hotel services largely draws from the achievements of the digital revolution.

Purpose of the article: The aim of the article is to present modern ICT solutions used in the hotel industry and to present the opinions of the owners of year-round accommodation facilities in the Lublin voivodeship on the impact of technological environment factors on the development of their companies.

Research methods: To achieve the article's aim, source materials are analysed concerning the subject matter and the findings from the author's own study, conducted in April and May 2018 using the CATI method.

Main findings: Entrepreneurs who participated in the study see the potential of the Internet as a technical means which facilitates access to potential customers. An alarming finding of the study is the low level of awareness among the respondents as to the significance of modern technological solutions which are essential for the hotel product and are the source of companies' competitive advantage.
\end{abstract}




\section{Introduction}

Dynamically developing informational technologies belong to the most essential factors of the modern market development (Panasiuk, 2015, p. 101). In recent years, innovative technical solutions in the tourism sector, in the scope of new types of tourism and of innovative technological tools (recommendation systems, virtual reality, etc.) have reduced the costs of service delivery and modified the traditional marketing mix components (Shaw \& Williams, 2009, p. 325). Technological changes have revolutionised the entire tourism sector, including hospitality (Ramli, 2015, p. 46). Therefore, the future of the hotel industry does not seem to be dependent so much on the size of the company but on the application of innovative ICT solutions, combined with the presence of professional staff (Kasim et al., 2013, p. 165). The introduction of modern technologies leads to a highly advantageous position in the competitive hotel industry, although numerous hotels are still reluctant to apply ICT solutions (Michalic \& Buhalis, 2013, p. 33). Against this background, the subject of modern technological solutions for the hotel market seems to be of great significance.

The aim of the article is to present the modern ICT ${ }^{1}$ (information and communication technologies) solutions applied in hospitality. These solutions are also interchangeably called telecommunications or information technologies which embrace a group of technologies which process, collect and send information in an electronic form (GUS, 2018, p. 11). The article also aims to present the opinions of the owners of year-round accommodation facilities which operate in the Lublin voivodeship concerning the impact of technological environment factors on the development of their companies.

\section{Literature review}

The implementation of ICT solutions in the hotel industry includes four categories: "web-based technologies, customer-related technology, business2business technology and information systems" (Cilan et al., 2007, p. 208). Barjaktarović enumerates the following uses of implementing ICT solutions in the hotel industry: "the Internet, intranet, extranet, applications used for reservation management, supply,

1 The term "ICT technology" embraces a wide range of all technologies which facilitate information manipulation and transmission. The conceptual range of ICT technology includes all communication media (Internet, wireless networks, bluetooth networks, landline, mobile and satellite telephony, sound and image communication technologies, radio, TV, etc.) and media which enable the storage of information (portable memory, hard drives, CDs/DVDs, tapes, etc.) as well as the equipment which enables information processing (personal computers, servers, clusters, computer networks, etc.). Additionally, ICT technologies embrace the whole range of IT applications and complex IT systems which facilitate data processing and transfer at a higher level of abstraction than the equipment level (Stownik pojęć strategii..., 2013, p. 26). 
selling, finances, accounting, decision support systems, management information systems, data bases, computer reservation systems, global distribution systems, destination management systems, interactive digital television, touch screen terminals" (Barjaktarović, 2013, p. 242).

Various factors contribute to the range of ICT solutions implemented by hotel companies. They include the size and type of the company, its structure, management style and culture (Michalic \& Buhalis, 2013, p. 38) as well as proper financial means (Sharma, 2015, p. 11).

ICT solutions are frequently applied in the hotel industry, particularly in the following spheres: "front office (reservation, check-in, payment), back office (finances and accounting, marketing, human resources, hotel housekeeping), tourist services, communication with tourists and partners, marketing research, monitoring of productivity and profitability indicators, control of business processes and staff" (Čerović \& Batić, 2014, p. 708). The introduction of ICT solutions greatly impacts the quality of hotel services and what follows leads to the growing satisfaction of hotel customers.

The use of modern technologies concerning guest service, personalisation and the enrichment of the guest experience has been drawing the attention of major hotel chains for several years. The Accor Hotels, Hilton Worldwide and Marriott International chains in particular invest in the implementation of modern technologies in hospitality. ${ }^{2}$

The hotel industry adapts virtual reality (VR) solutions. The technology uses pictures, sounds and physical sensations so that their users can feel as if they are physically present in the real, not virtual, world. ${ }^{3}$ Although VR offers considerable benefits to the tourism sector, it may also create certain limitations. Research shows that VR, as an interesting and convenient electronic alternative, may decrease the need to travel. Other findings, however, indicate that VR largely motivates tourists to really discover locations displayed earlier in a virtual form (Pantano \& Servidio, 2012, p. 55).

Augmented reality is also becoming a frequent phenomenon in hospitality. This technology improves the physical environment. Computer-generated interactive elements (signs, pictures, diagrams, maps, photos) do not create an entirely new virtual world (as is the case in VR) but rather enrich and complement the unchanged real world. A new "virtual layer" is compatible with real objects and fits into their landscape. Augmented reality recognises real world objects and then adds virtual information (Kalecińska, 2013, p. 33).

\footnotetext{
2 http://www.enjoyyourstay.pl/2018-rokiem-kolejnych-nowosci-hotelarstwie/ [access: 14.01.2019].

3 https://mojafirma.infor.pl/nieruchomosci/wiadomosci/nieruchomosci-komercyjne/2703077,2, Nowoczesne-technologie-w-branzy-hotelarskiej.html [access: 14.01.2019].
} 


\section{Research methodology}

In order to gather the opinions of the owners of year-round accommodation facilities in the Lublin voivodeship concerning the impact of technological environment factors on the development of their companies, field research was conducted in April and May 2018. The CATI (computer-assisted telephone interviewing) method was used. The subjective scope of the research includes year-round accommodation facilities. The size of the research sample amounts to 110 entities. The dominant type consisted of other hotel facilities ${ }^{4}-38.2 \%$. A considerable group was represented by hotels $(24.6 \%)$ and guest rooms or private accommodation $(22.8 \%)$. The study was also conducted in guesthouses ( $4.5 \%$ of all entities), motels $(3.6 \%)$, training-recreational centres $(2.7 \%)$, public tourist cottages $(1.8 \%)$, a hostel $(0.9 \%)$ and a spa facility $(0.9 \%)$. Due to the organisational and legal form, the sample structure was dominated by natural persons conducting economic activity $(86.4 \%$ of all entities in the study). The study also included civil-law companies (9.1\%), budgetary units $(2.7 \%)$, a general partnership $(0.9 \%)$ and a limited liability company $(0.9 \%)$. More than half of the entities (66.4\%) had been operating for over 5 years, while $21.8 \%$ of the entities had been operating for 3-5 years and $11.8 \%$ had been operating for $1-3$ years.

While selecting the research sample units, the stratified sampling method was used. The type of a year-round accommodation facility was the stratum, according to the typology provided by Statistics Poland. The number of units in the research sample in particular strata in counties depended on the number of these units in the general population in the same counties. In order to specify the structure of the general population regarding the types of year-round accommodation facilities, the data from Statistics Poland, available on the Internet, in the Local Data Bank, were used. ${ }^{5}$ The number of the general population amounted to 290 entities (as of 31 July 2017). The respondents (research units) were owners of the companies providing year-round accommodation services (entrepreneurs). In order to present the study in terms of statistics, the structure indices, medians and modes were calculated, based on the responses obtained. The Kruskal-Wallis test was used to specify the statistically significant differences between the responses of the respondents operating in various types of communes.

4 Other hotel facility - a hotel facility, divided into rooms, managed by one management board, providing some services, which include cleaning rooms, making beds and cleaning sanitary equipment every day (e.g. a facility which serves as a hotel, motel or guesthouse which has been assigned no category), https://stat.gov.pl/metainformacje/slownik-pojec/pojecia-stosowane-w-statystyce-publicznej/1288,pojecie.html [access:14.01.2019].

5 https://bdl.stat.gov.pl/BDL/dane/podgrup/tablica [access:14.01.2019]. 


\section{Results}

The results indicate that the majority of the respondents consider modern technological solutions as factors which rather or definitely support the development of their companies. The detailed results of the study are displayed in Figure 1.

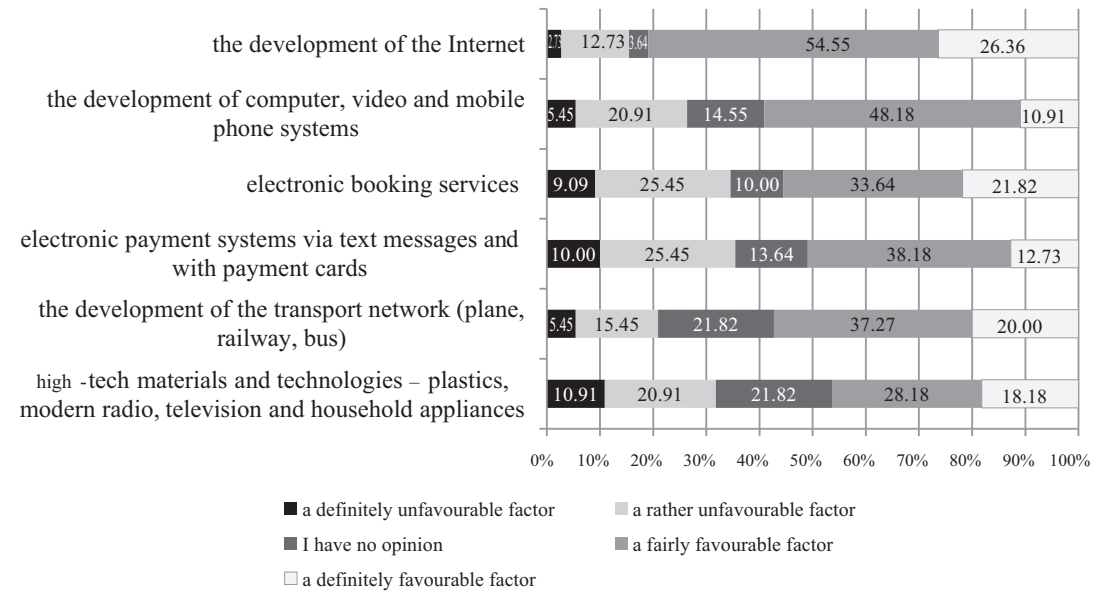

Figure 1. The impact of technological environment factors on the development of companies providing accommodation services in the Lublin voivodeship - the response structure (\%)

Source: Author's own study.

The middle value (median) for all evaluated factors of a company's technological environment amounts to 4 (a fairly favourable factor), which means that $50 \%$ of the study results are placed over or below this value in the 1-5 scale. The respondents most frequently considered technological environment factors as fairly favourable in the context of the development of companies providing accommodation services. The values of the median and the mode for the factors included in the study in various types of communes and in total are presented in Table 1.

Table 1. The impact of technological environment factors on the development of companies providing accommodation services in the Lublin voivodeship - the median and the mode

\begin{tabular}{|l|c|c|c|c|c|c|c|c|}
\hline \multirow{2}{*}{$\begin{array}{c}\text { Factors of technological environment } \\
\text { of the company }\end{array}$} & \multicolumn{2}{|c|}{$\begin{array}{c}\text { Urban } \\
\text { communes }\end{array}$} & \multicolumn{2}{c|}{$\begin{array}{c}\text { Urban-rural } \\
\text { communes }\end{array}$} & \multicolumn{2}{c|}{$\begin{array}{c}\text { Rural } \\
\text { communes }\end{array}$} & \multicolumn{3}{c|}{ Total } \\
\cline { 2 - 19 } & $\begin{array}{c}\text { Median } \\
(\mathrm{Me})\end{array}$ & $\begin{array}{c}\text { Mode } \\
(\mathrm{Mo})\end{array}$ & $\begin{array}{c}\text { Median } \\
(\mathrm{Me})\end{array}$ & $\begin{array}{c}\text { Mode } \\
(\mathrm{Mo})\end{array}$ & $\begin{array}{c}\text { Median } \\
(\mathrm{Me})\end{array}$ & $\begin{array}{c}\text { Mode } \\
(\mathrm{Mo})\end{array}$ & $\begin{array}{c}\text { Median } \\
(\mathrm{Me})\end{array}$ & $\begin{array}{c}\text { Mode } \\
(\mathrm{Mo})\end{array}$ \\
\hline the development of the Internet & 4.0 & 4.0 & 4.0 & 4.0 & 4.0 & 4.0 & 4.0 & 4.0 \\
\hline $\begin{array}{l}\text { the development of computer, video } \\
\text { and mobile phone systems }\end{array}$ & 4.0 & 4.0 & 4.0 & 4.0 & 4.0 & 4.0 & 4.0 & 4.0 \\
\hline electronic booking services & 4.0 & 4.0 & 4.0 & 2.0 & 3.0 & 2.0 & 4.0 & 4.0 \\
\hline $\begin{array}{l}\text { electronic payment systems via text } \\
\text { messages and with payment cards }\end{array}$ & 4.0 & 4.0 & 3.0 & 4.0 & 3.0 & 2.0 & 4.0 & 4.0 \\
\hline
\end{tabular}


Pobrane z czasopisma Annales H - Oeconomia http://oeconomia.annales.umcs.pl Data: 26/04/2023 12:01:25

\begin{tabular}{|l|c|c|c|c|c|c|c|c|}
\hline \multirow{2}{*}{$\begin{array}{l}\text { Factors of technological environment } \\
\text { of the company }\end{array}$} & \multicolumn{2}{|c|}{$\begin{array}{c}\text { Urban } \\
\text { communes }\end{array}$} & \multicolumn{2}{c|}{$\begin{array}{c}\text { Urban-rural } \\
\text { communes }\end{array}$} & \multicolumn{2}{c|}{$\begin{array}{c}\text { Rural } \\
\text { communes }\end{array}$} & \multicolumn{2}{c|}{ Total } \\
\cline { 2 - 10 } & $\begin{array}{c}\text { Median } \\
\text { (Me) }\end{array}$ & $\begin{array}{c}\text { Mode } \\
\text { (Mo) }\end{array}$ & $\begin{array}{c}\text { Median } \\
\text { (Me) }\end{array}$ & $\begin{array}{c}\text { Mode } \\
\text { (Mo) }\end{array}$ & $\begin{array}{c}\text { Median } \\
\text { (Me) }\end{array}$ & $\begin{array}{c}\text { Mode } \\
\text { (Mo) }\end{array}$ & $\begin{array}{c}\text { Median } \\
\text { (Me) }\end{array}$ & $\begin{array}{c}\text { Mode } \\
\text { (Mo) }\end{array}$ \\
\hline $\begin{array}{l}\text { the development of the transport } \\
\text { network (plane, railway, bus) }\end{array}$ & 4.0 & 4.0 & 4.0 & 4.0 & 4.0 & 4.0 & 4.0 & 4.0 \\
\hline $\begin{array}{l}\text { high-tech materials and technologies - } \\
\text { plastics, modern radio, television and } \\
\text { household appliances }\end{array}$ & 4.0 & 4.0 & 3.0 & 5.0 & 4.0 & 4.0 & 4.0 & 4.0 \\
\hline
\end{tabular}

The numbers reflect the values in the scale $1-5$ where: 1 - a definitely unfavourable factor, 2 - a rather unfavourable factor, 3 - I have no opinion, 4 - a fairly favourable factor, 5 - a definitely favourable factor.

Source: Author's own study.

In the study, the respondents estimated the need for further development of technological environment factors. The largest group of the study participants feels a strong need $-15.45 \%$ and a very strong need $-37.27 \%$ for the development of transport networks in the Lublin voivodeship which would facilitate the development of tourist traffic in this area. The results of the study are displayed in Figure 2.

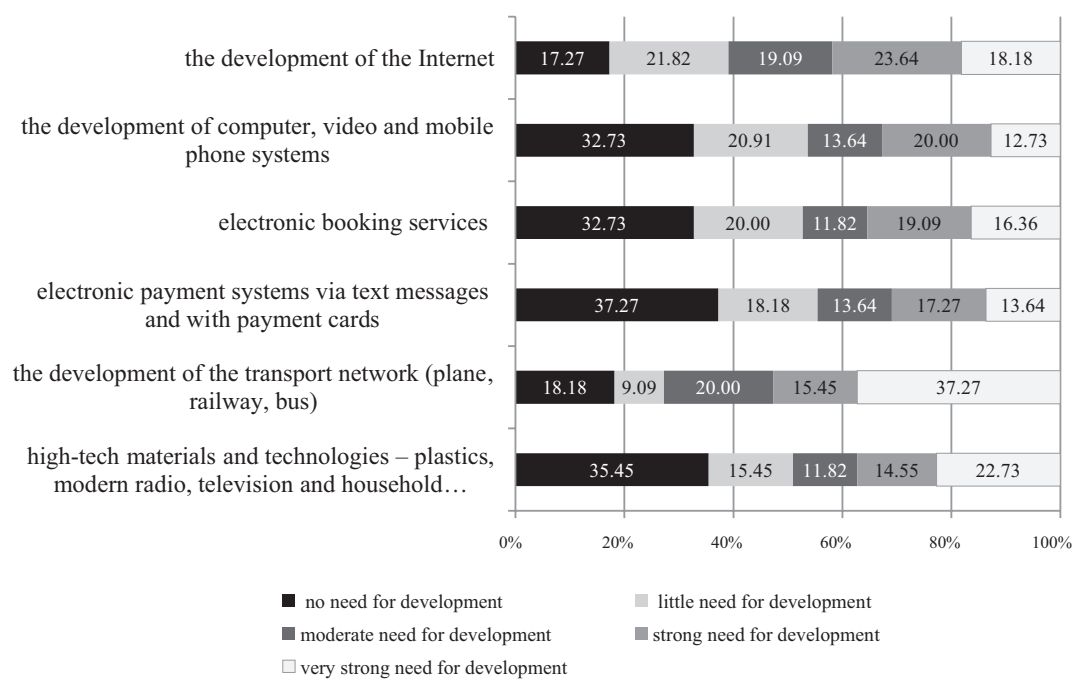

Figure 2. The need for further development of technological environment factors - the response structure (\%)

Source: Author's own study.

The analysis of the study findings reveals that the middle value (the median) for the factor of transport network development amounts to 4 - a strong need for development in the 1-5 scale. This result means that the same number of observations is visible over and below this value. The median for the Internet development factor amounts to 3 - a moderate need for development. The middle value for the development of computer, video and mobile phone systems as well as electronic 
booking systems, electronic payment systems via text messages and with payment cards, and high-tech materials and technologies is 2 - little need for development. The study results, taking various commune types into account, are displayed in Table 2.

Table 2. The need for further development of technological environment factors - the median and the mode

\begin{tabular}{|l|c|c|c|c|c|c|c|c|}
\hline \multirow{2}{*}{$\begin{array}{c}\text { Factors of technological } \\
\text { environment of the company }\end{array}$} & \multicolumn{2}{c|}{$\begin{array}{c}\text { Urban } \\
\text { communes }\end{array}$} & \multicolumn{2}{c|}{$\begin{array}{c}\text { Urban-rural } \\
\text { communes }\end{array}$} & \multicolumn{2}{c|}{$\begin{array}{c}\text { Rural } \\
\text { communes }\end{array}$} & \multicolumn{3}{c|}{ Total } \\
\cline { 2 - 20 } & $\begin{array}{c}\text { Me- } \\
\text { dian } \\
(\mathrm{Me})\end{array}$ & $\begin{array}{c}\text { Mode } \\
(\mathrm{Mo})\end{array}$ & $\begin{array}{c}\text { Me- } \\
\text { dian } \\
(\mathrm{Me})\end{array}$ & $\begin{array}{c}\text { Mode } \\
(\mathrm{Mo})\end{array}$ & $\begin{array}{c}\text { Me- } \\
\text { dian } \\
(\mathrm{Me})\end{array}$ & $\begin{array}{c}\text { Mode } \\
(\mathrm{Mo})\end{array}$ & $\begin{array}{c}\text { Me- } \\
\text { dian } \\
(\mathrm{Me})\end{array}$ & $\begin{array}{c}\text { Mode } \\
(\mathrm{Mo})\end{array}$ \\
\hline the development of the Internet & $4.0^{\mathrm{a}}$ & $4.0^{\mathrm{a}}$ & $2.0^{\mathrm{a}}$ & $1.0^{\mathrm{a}}$ & 3.0 & 2.0 & 3.0 & 4.0 \\
\hline $\begin{array}{l}\text { the development of computer, video } \\
\text { and mobile phone systems }\end{array}$ & 3.0 & 4.0 & 2.0 & 1.0 & 2.0 & 1.0 & 2.0 & 1.0 \\
\hline electronic booking services & 3.0 & 4.0 & 2.0 & 1.0 & 2.0 & 1.0 & 2.0 & 1.0 \\
\hline $\begin{array}{l}\text { electronic payment systems via text } \\
\text { messages and with payment cards }\end{array}$ & 3.0 & 1.0 & 1.5 & 1.0 & 2.0 & 1.0 & 2.0 & 1.0 \\
\hline $\begin{array}{l}\text { the development of the transport } \\
\text { network (plane, railway, bus) }\end{array}$ & $4.0^{\mathrm{a}, \mathrm{b}}$ & $5.0^{\mathrm{a}}$ & $3.0^{\mathrm{a}}$ & $1.0^{\mathrm{a}}$ & $3.0^{\mathrm{b}}$ & $(-)$ & 4.0 & 5.0 \\
\hline $\begin{array}{l}\text { high-tech materials and technologies } \\
\text { - plastics, modern radio, television } \\
\text { and household appliances }\end{array}$ & 3.0 & $(-)$ & 1.5 & 1.0 & 2.0 & 1.0 & 2.0 & 1.0 \\
\hline
\end{tabular}

$\mathrm{a}, \mathrm{b}-$ indicate an essential difference between a given pair of values $(\mathrm{p}<0.05)$.

The numbers reflect the values in the scale 1-5 where: 1 - no need for development, 2 - little need for development,

3 - moderate need for development, 4 - strong need for development, 5 - very strong need for development.

Source: Author's own study.

As Table 2 shows, the greatest concentration of study results for the factor of transport network development is on the value of 5 - very strong need for development. The most numerous group of respondents feels a strong need for the development of the Internet - the mode for the assessment of this factor amounts to 4 . The remaining technological environment factors, included in the study, are most frequently estimated as 1 - no need for development.

\section{Discussion}

Numerous studies confirm the great impact of ICT technology and the Internet on the functioning of companies (Olszewska \& Kubicka, 2010, p. 10). Analysts of the market of tourist services, including the market of hotel services, agree with this statement. According to Milewska and Włodarczyk, technological environment factors have a strong influence on the operation of the hotel industry, which manifests itself in the modernisation of hotel equipment and in the increasing automation of hotel services (Milewska \& Włodarczyk, 2009, p. 339).

This conviction is shared by Matusiak et al. who argue that the main factor of the changes, which has an impact on the development of companies, is the dynamic 
development of modern technologies (Matusiak et al., 2009). Due to the development of ICT technology and services, companies have obtained a greater access to information. As a consequence, new markets and products have been developing and service providers have entered a higher level of interaction with customers on the Internet. The "new possibilities" situation may become a way of developing and improving the domestic markets due to the effective and rational use of ICT technology by domestic companies (Stecyk, 2009, p. 90).

The entrepreneurs participating in the study seem to see the potential of the Internet as a technical means of accessing potential customers. They perceive it as a factor which largely impacts the development possibilities of hotel companies. The assessment of other technological environment factors included in the study may mean that the study participants are not aware of the chances brought by the development of technology which might successfully render the hotel product more attractive. A disturbing finding is the moderate or low demand from the respondents for the development of new technologies and technical solutions which might be useful in hospitality. The opinions of the entrepreneurs who took part in the study are not compatible with the results of analyses conducted so far by researchers on the market of hotel services.

\section{Conclusions}

In 2020, the generation of people born between 1980 and 1994 will total over $50 \%$ of all hotel guests (Szymczyk, 2018, p. 46). The age structure of hotel guests will have an impact on their expectations concerning the hotel product, the attractiveness of which will largely be influenced by intelligent solutions based on modern technologies. Soon, systems of booking process automation, cloud technologies, smartphone applications, mobile room keys or a virtual concierge on the tablet will be the basic equipment of the majority of hotels, as used to be the case with a telephone or cable television in the hotel room (Noga, 2018, p. 47). Nowadays, the introduction of modern ICT solutions in the hotel industry is becoming an essential element of competitiveness in the market of hotel services.

For the entrepreneurs - the owners of year-round accommodation facilities in the Lublin voivodeship, technological environment factors are the solutions which are fairly favourable for the development of the entities in the study. Unfortunately, the respondents do not see any strong need to develop the aforementioned technological environment factors, with the exception of the improvement of the road and Internet networks. For entrepreneurs, these features are not particularly important in the development of their companies. The results of the study should be of concern, as they show a low level of awareness among the respondents concerning the significance of ICT solutions. The entrepreneurs who participated in the study perceive the potential of the Internet as a factor in the development of their economic entities. 
The greatest opportunity is perceived, however, in the development of the transport infrastructure which is a necessary condition of the development of tourist traffic in the Lublin voivodeship.

As far as the development of accommodation services is concerned, it is highly important that the owners of hotel facilities should feel the need to develop their offer through the implementation of improvements for their customers which are based on ICT solutions. Only this way of thinking and acting will facilitate efficient competition in an increasingly demanding market.

\section{Appendix - The questions asked in the interview questionnaire}

1. Are the following factors favourable for the current development of your company? Please mark the answer for each item on the 1-5 scale where: $1-$ a definitely unfavourable factor, 2 - a rather unfavourable factor, 3 - I have no opinion, 4 - a fairly favourable factor, 5 - a definitely favourable factor.

\begin{tabular}{|c|c|c|c|c|c|}
\hline \multirow{2}{*}{$\begin{array}{l}\text { Technological factors which influence the development of companies } \\
\text { providing accommodation services }\end{array}$} & \multicolumn{5}{|c|}{ Impact of factors } \\
\hline & 1 & 2 & 3 & 4 & 5 \\
\hline \multicolumn{6}{|l|}{ the development of the Internet } \\
\hline \multicolumn{6}{|l|}{ the development of computer, video and mobile phone systems } \\
\hline \multicolumn{6}{|l|}{ electronic booking services } \\
\hline \multicolumn{6}{|l|}{ electronic payment systems via text messages and with payment cards } \\
\hline \multicolumn{6}{|l|}{ the development of the transport network (plane, railway, bus) } \\
\hline $\begin{array}{l}\text { high-tech materials and technologies - plastics, modern radio, television } \\
\text { and household appliances }\end{array}$ & & & & & \\
\hline
\end{tabular}

2. Please specify the need for the further development of factors which contribute to the development of your company on the 1-5 scale, where: 1 - no need for development, 2 - little need for development, 3 - moderate need for development, 4 - strong need for development, 5 - very strong need for development.

\begin{tabular}{|c|c|c|c|c|c|}
\hline \multirow{2}{*}{$\begin{array}{l}\text { Technological factors which influence the development of companies } \\
\text { providing accommodation services }\end{array}$} & \multicolumn{5}{|c|}{ The need for development } \\
\hline & 1 & 2 & 3 & 4 & 5 \\
\hline \multicolumn{6}{|l|}{ the development of the Internet } \\
\hline \multicolumn{6}{|l|}{ the development of computer, video and mobile phone systems } \\
\hline \multicolumn{6}{|l|}{ electronic booking services } \\
\hline \multicolumn{6}{|l|}{ electronic payment systems via text messages and with payment cards } \\
\hline \multicolumn{6}{|l|}{ the development of the transport network (plane, railway, bus) } \\
\hline $\begin{array}{l}\text { high-tech materials and technologies - plastics, modern radio, television } \\
\text { and household appliances }\end{array}$ & & & & & \\
\hline
\end{tabular}




\section{References}

Barjaktarović, D. (2013). Quality management in hospitality. Belgrade: Singidunum University.

Čerović, S., \& Batić, S. (2014). Information systems support to the hospitality management of Novi Sad. In: M. Stanisić (Ed.), Sinteza 2014 - Impact of Internet on Business Activities in Serbia and Worldwide. Belgrade: Singidunum University. DOI: 10.15308/sinteza-2014-706-714.

Cilan, C.A., Balaban, E., Coskun, E., \& Sharma, D. (2007). An exploratory study of information technology utilization and its influence on business performance of upscale hotel industry in Turkey. International Journal of Business Strategy, 7(2).

GUS (2018). Spoteczeństwo informacyjne w Polsce. Wyniki badań statystycznych z lat 2014-2018. Warszawa-Szczecin: Urząd Statystyczny w Szczecinie.

Kalecińska, J. (2013). Nowe technologie w branży turystycznej. Warszawa: Akademia Wychowania Fizycznego.

Kasim, A., Dzakiria, H., \& Scarlat, C. (2013). Exploring the digital divide issues affecting hotel frontliners. Advances in Business - Related Scientific Research Journal, 4(2).

Matusiak, B., Kuciński, J., \& Gryzik, A. (2009). Foresight kadr nowoczesnej gospodarki. Warszawa: Polska Agencja Rozwoju Przedsiębiorczości.

Michalic, T., \& Buhalis, D. (2013). ICT as a new competitive advantage factor - case of small transitional hotel sector. Economic and Business Review, 15(1).

Milewska, M., \& Włodarczyk, B. (2009). Hotelarstwo. Warszawa: PWE.

Noga, R. (2018). Obsługa gościa z Concierge Tablet. Hotelarz, August.

Olszewska, B., \& Kubicka, J. (2010). Zmiany w zarządzaniu przedsiębiorstwami w warunkach współczesnych zmian w otoczeniu. Wrocław: Wyższa Szkoła Handlowa.

Panasiuk, A. (2015). Nowoczesne technologie informacyjne w kształtowaniu innowacji na rynku turystycznym. Rozprawy Naukowe Akademii Wychowania Fizycznego we Wrocławiu, 49.

Pantano, E., \& Servidio, R. (2012). Advanced technologies and tourist behaviour: The case of pervasive environments. In: P. Ordóñez de Pablos, R. Tennyson, J. Zhao (Eds.), Global Hospitality and Tourism Management Technologies (pp. 52-71). Hershey: Business Science Reference.

DOI: 10.4018/978-1-61350-041-5.ch004.

Ramli, A. (2015). The status of accounting information systems (AIS) adoption in the hotel industry. Journal of Entrepreneurship and Business, 3(1). DOI: 10.17687/JEB.0301.04.

Sharma, A. (2015). A review study on the information technology applications in the hotel industry. Scholedge International Journal of Business Policy \& Governance, 2(2).

Shaw, G., \& Williams, A. (2009). Knowledge transfer and management in tourism organizations: An emerging research agenda. Tourism Management, 30(3). DOI: 10.1016/j.tourman.2008.02.023.

Stownik pojęć strategii rozwoju transportu do 2020 roku (z perspektywa do 2030 roku), (2013). Warszawa: Ministerstwo Transportu, Budownictwa i Gospodarki Morskiej.

Stecyk, A. (2009). Wykorzystanie technologii ICT w Polsce - w świetle badań Światowego Forum Ekonomicznego. e-mentor, 3(30).

Szymczyk, A. (2018). Po pierwsze gość, po drugie technologia. Hotelarz, August.

\section{Internet sources}

http://www.enjoyyourstay.pl [access: 14.01.2019].

https://bdl.stat.gov.pl [access: 14.01.2019].

https://mojafirma.infor.pl/ [access: 14.01.2019].

https://stat.gov.pl/ [access: 14.01.2019]. 